\title{
Protective effects of mulberry (Morus alba) sugar extracts on hydrogen peroxide-induced oxidative stress in HepG2 cell
}

\author{
Young Youn, Ha-Yan Kim, Hoe-Man Park, Sun-Ho Lee, Jong-Ryul Park, \\ Seong-Gi Hong, Young-Geun Kim* \\ National Academy of Agricultural Science, Rural Development Administration, Jeonju 54875, Korea
}

\section{오디 당침출액의 HepG2 세포에서 $\mathrm{H}_{2} \mathrm{O}_{2}$ 로 야기된 산화적 스트레스 보호 효과}

\author{
윤영 · 김하얀 · 박회만 · 이선호 · 박종률 · 홍성기 · 김영근* \\ 농촌진흥청 국립농업과학원 농업공학부
}

\begin{abstract}
The objective of this study was to investigate the protective effects of mulberry (Morus alba) sugar extracts (MSE) against $\mathrm{H}_{2} \mathrm{O}_{2}$-induced oxidative stress in HepG2 cells. The MSEs was mixed with matured mulberry and sugar at the same ratio $(1: 1, \mathrm{w} / \mathrm{w})$ and stored at $18 \pm 3^{\circ} \mathrm{C}$ for 40 days. In 2,2-diphenyl-1-picryl-hydrazyl (DPPH) radical scavenging test, MSE stored for 40 days showed high activity with a ratio above $66 \%$. Therefore, we selected 40 days as the optimum storage period. After cell viability analysis using the 3-(4,5-dimethylthiazol-2-yl)2,5-diphenyltetrazolium bromide (MTT) assay, we determined that the optimum concentration of MSE was $0.5 \%$. Our results showed that MSE increased the cell viability and antioxidant enzyme activities of superoxide dismutase (SOD) and catalase in $\mathrm{H}_{2} \mathrm{O}_{2}$-treated $\mathrm{HepG} 2$ cells. Moreover, the treatment with MSE inhibited malondialdehyde (MDA) levels in $\mathrm{H}_{2} \mathrm{O}_{2}$-treated HepG2 cells. We also observed a reduction in apoptotic bodies in the Hoechst staining. These data show that MSE treatment significantly suppressed caspase-3 activity in HepG2 cells expored to $\mathrm{H}_{2} \mathrm{O}_{2}$-induced oxidative stress, thereby indicationg the protective effects of MSE in $\mathrm{H}_{2} \mathrm{O}_{2}$-induced oxidative stress.
\end{abstract}

Key words : mulberry (Morus alba), sugar extracts, $\mathrm{H}_{2} \mathrm{O}_{2}$, oxidative stress

\section{서 론}

생체 내에서 에너지 공급을 위해 생화학적 반응이 지속 적으로 일어나는 과정에서 발생되는 활성산소(reactive oxygen species, ROS)는, 항산화 효소계 등 자기 방어 기구 의 제거 시스템으로 인해 소거되어 생체 내 평형을 유지하 지만, 어떤 특수한 상황(과도한 스트레스, 과식, 음주, 흡연, 방사선, 초음파, 환경오염 및 약물 섭취 등)에서는 생체 내 균형이 깨지면서 활성산소가 과잉으로 생성된다(1). 과 잉 생산된 활성산소는 $\mathrm{DNA}$, 단백질 및 지방의 심한 손상을

*Corresponding author. E-mail : ykkim@korea.kr Phone : 82-63-238-4042, Fax : 82-63-238-4105

Received 5 August 2015; Revised 12 October 2015; Accepted 14 October 2015.

Copyright (c) The Korean Society of Food Preservation. All rights reserved.
일으켜 산화적 스트레스에 노출되며, 이러한 산화적 스트 레스는 다양한 기전을 통하여 암, 염증, 심장질환, 당뇨병, 비만 및 노화의 중요 병인으로 알려져 있다(2). 이에 산화적 스트레스에 대항하는 방어기전 향상을 목적으로, 몇 가지 합성 항산화제(synthetic antioxidants)에 대하여 질병의 예 방과 치료를 위해 사용되고 있으나, 이들의 여러 가지 부작 용과 독성에 대한 문제로 인해 천연의 항산화제를 통한 부작용을 줄이고자 식품이나 천연물에 함유된 항산화물질 에 대한 연구가 활발히 진행되고 있다(3).

오디는 뽕나무(Morous alba L.)과에 속하는 낙엽교목인 뽕나무 열매로 한방에서는 상심(桑椹), 상실(桑實) 또는 흑 심(黑椹) 등으로 지칭되며, 동의보감 탕액편에는 '오디는 성질이 차고 맛이 달며 독이 없고, 당뇨(소갈)을 덜어주며, 오장을 편하게 하고, 오래먹으면 배가 고프지 않게 된다'고 하며, '오디를 오래 먹으면 백발이 검게 변하고, 노화를 방지한다'고 기록되어 있다(4,5). 또한, 완숙 오디는 당도가 
높고 식감이 좋으며, 다량의 glucose와 fructose를 함유하고 (6), oxalic acid, citric acid, malic acid, succinic acid 및 acetic acid와 같은 유기산(7), polyphenol 및 cyanidin-3-glucoside 와 cyanidin-3-rutinoside 같은 anthocyanin 계통의 색소 등을 다량 함유하고 있어(8), 식품에 첨가 시 색이 우수할 뿐 아니라, 항산화, 항당뇨, 항고지혈증 등의 다양한 생리활성 효과도 알려지면서 인체에 무해한 천연색소 및 기능성 소재 로 각광받고 있다(9-11). 하지만, 오디의 과실은 쉽게 물러 지고, 수분함량이 높아 수확 작업이 어렵고, 쉽게 부패되며 저장성이 떨어져 생과로서의 이용이 불안정하므로 다양한 가공 제품 형태로의 적용이 요구된다(12). 현재까지 오디를 이용한 기능성 식품에 관한 연구로 오디를 첨가한 제과 및 제빵(13-16), 오디를 첨가한 떡(17), 오디를 첨가한 샐러 드드레싱(18), 오디를 첨가한 술(4,19,20) 등 최근 들어 연구 의 폭이 다양해지고 있으나, 오디를 이용한 당침출액에 관 련된 성분 분석 및 기능성 연구들에 대해 아직 미비한 실정 이다.

따라서, 본 연구에서는 최근 건강식품으로 각광받고 있 는 오디를 이용하여 전통발효 공정을 활용한 오디 당침출액 을 제조하고, 오디 당침출액의 in vitro 내에서의 산화적 스트레스에 대한 보호 효과를 규명함으로써, 오디 당침출 액에 대한 기초자료를 제공하고자 하였다.

\section{재료 및 방법}

\section{오디 당침출액의 제조}

본 실험에 사용된 오디(Morus alba)는 2014년 전북 고창 에서 생산된 것으로 고창 농가를 통해 직접 구입하여 전통 적인 방법에 따라 오디 침출액을 제조하였다. 즉, 잘 익은 오디를 꼭지와 이물질을 제거하여 동량의 설탕(Qone white sugar, Samyang Co., Ulsan, Korea)을 넣고 밀봉시켜 상온 $\left(18 \pm 3^{\circ} \mathrm{C}\right)$ 에서 40 일간 보관하였다. 이후 오디는 건져 내고 얻은 침출액을 $4^{\circ} \mathrm{C}$ 의 냉장고에 보관하면서 실험에 사용하 였다.

\section{DPPH radical scavenging activity 측정}

오디 당침출액을 10 일 간격으로 40 일 동안 항산화 효능 을 비교하고, 결과를 바탕으로 시료를 선택하여, 이후 세포 관련 실험에 사용하고자 하였고, 항산화 효능을 측정하기 위해 1,1-diphenyl-2-pycrylhydrazyl(DPPH, Sigma Chemical Co., St. Louis, MO, USA)을 이용하였다. 즉, $0.2 \mathrm{mM} \mathrm{DPPH}$ 용액 $0.8 \mathrm{~mL}$ 에 시료 $0.2 \mathrm{~mL}$ 를 첨가하여 혼합한 다음 실온에 서 30 분간 반응시킨 다음 $517 \mathrm{~nm}$ 에서 흡광도를 측정하였다.

\section{세포배양}

본 실험에 사용된 세포는 인간 간암세포주인 $\mathrm{HepG} 2$ 로
American Type Culture collection(ATCC, Manassas, VA, USA)에서 구입하여, $10 \%$ fetal bovine serum(FBS, Hyclone, Logan, UT, USA)를 첨가한 DMEM(Hyclone) 배지를 사용 하여 $37^{\circ} \mathrm{C}, 5 \% \mathrm{CO}_{2}$ incubator에서 배양시키고, 세포 밀도가 $90 \%$ 로 포화되었을 때 계대 배양하여 실험에 사용하였다.

\section{MTT assay}

HepG2 세포에 대한 오디 당침출액의 세포 독성 및 산화 적 스트레스에 의한 당침출액의 세포 보호효과 측정을 위해 MTT assay를 시행하였다. 즉, HepG2 세포를 96 well plate에 분주 $\left(1 \times 10^{4} \mathrm{cell} / \mathrm{mL}\right)$ 하고, 24 시간 동안 배양 $\left(37^{\circ} \mathrm{C}, 5 \% \mathrm{CO}_{2}\right)$ 시킨 다음, 시료를 농도별로 세포에 처리하고, $37^{\circ} \mathrm{C}$ 배양기 에서 반응시켰다. 24시간 후 $500 \mu \mathrm{M}$ 의 과산화수소 $\left(\mathrm{H}_{2} \mathrm{O}_{2}\right)$ 를 처리하고 배양기에서 4 시간 동안 방치하였다. 배양이 끝난 후 배양액을 제거하고 각 well에 3-(4,5-di-methylthiazol-2yl)-2,5-diphenyl tetrazolium bromide(MTT, Sigma-Aldrich Co., St. Louis, MO, USA, $5 \mathrm{mg} / \mathrm{mL}$ )을 $30 \mu \mathrm{L}$ 씩 넣고 2 시간 동안 반응시켜 배양 상등액을 제거하고, dimethyl sulfoxide (DMSO, Sigma-Aldrich Co.)를 $100 \mu \mathrm{L} /$ well씩 첨가하고 30 분 후 $517 \mathrm{~nm}$ 에서 흡광도를 측정하였다.

\section{Lipid peroxidation 측정}

지질과산화물 측정은 세포에 시료를 처리한 후 24시간 배양시켜 $250 \mu \mathrm{M}$ 의 $\mathrm{H}_{2} \mathrm{O}_{2}$ 를 처리하여 12시간 방치시킨 다 음, $25 \%$ trichloroacetic acid(TCA) $1 \mathrm{~mL}$ 와 $0.67 \%$ thiobabituric $\operatorname{acid}(\mathrm{TBA}) 1 \mathrm{~mL}$ 를 첨가하여 $95^{\circ} \mathrm{C}$ 에서 30 분간 가열하였다. 그 후 n-butanol $4 \mathrm{~mL}$ 를 첨가하고, 원심분리 $3,000 \mathrm{rpm}, 30$ $\min$ ) 시킨 다음, 상등액을 취하여 $532 \mathrm{~nm}$ 에서 흡광도를 측정하였다. 이때, 지질과산화물은 malondialdehyde(MDA) 의 양으로 환산하여 계산하였다(21).

\section{항산화 효소 측정}

HepG2 세포 내에서 항산화 효소는 superoxide dimutase (SOD) 및 catalase(CAT)의 활성으로 측정하였다. 배양된 세포에 시료를 처리하고 60 분간 반응시켜 trypsin으로 세포 를 걷어내고, phosphate-buffer saline(PBS)로 씻어 준 다음, lysis buffer(20 mM tris, $\mathrm{pH} 8.0,0.5 \mathrm{mM}$ EDTA, $0.2 \mathrm{M}$ sucrose)에서 sonication 하였다. 그 후 $1,5000 \mathrm{rpm}$ 에서 30 분 간 원심분리하여 단백질 추출물을 얻고, 황산화 효소 활성 에 사용하였다. SOD 활성은 $50 \mathrm{mM} \mathrm{PBS(pH} \mathrm{8.2)} 8.7 \mathrm{~mL}$ 에 세포 상등액을 넣고, $3 \mathrm{mM}$ pryogallol 용액 $0.3 \mathrm{~mL}$ 을 첨가하 여 $325 \mathrm{~nm}$ 에서 흡광도를 측정하였고, CAT 활성 측성은 $11 \mathrm{mM} \mathrm{H} \mathrm{H}_{2}$ 를 포함하는 $50 \mathrm{mM}$ potassium phosphate $\operatorname{buffer(pH~7.0)ㄹㅡㄹ~ㅅㅣㄹㅛㅇㅘ~ㅎㅗㄴㅎㅏㅂㅎㅏㄱㅗ,~} 240 \mathrm{~nm}$ 에서 흡광도를 측정하였다.

\section{Hoechst 33342 염색}

HepG2 세포를 6-well plate에 $2 \times 10^{5}$ cells/well로 분주한 
후 배양기에서 24시간 동안 배양하여 시료를 처리한 후, $500 \mu \mathrm{M} \mathrm{H}_{2} \mathrm{O}_{2}$ 를 처리하여 12시간 반응시킨 다음, $\mathrm{PBS}$ 완충 액으로 2회 세척하여 $10 \%$ formalin을 처리하여 4시간 고정 시켰다. 그 후, PBS로 세척하고 Hoechst 33342(SigmaAldrich Co.)로 30 분 동안 염색시키고, PBS로 세척하여 형 광 현미경 하에서 400 배로 관찰하였다.

\section{Caspase-3 활성 측정}

Caspase-3 활성은 ApoAlert caspase-3 colormetric assay kit(Clontech Co., CA, USA)를 이용하여 분석하였다. HepG2 세포를 6-well plate에 $1 \times 10^{6}$ cells/well로 24 시간 배양 후, 시료를 처리한 다음, $500 \mu \mathrm{M} \mathrm{H}_{2} \mathrm{O}_{2}$ 를 처리하여 12시간 반응 시킨 다음, 원심분리하여 상등액을 버리고 세포만을 얻었 다. 모아진 세포에 chilled cell lysis buffer를 첨가하여 10분 간 얼음위에 반응시킨 다음, 3 분간 원심분리 $\left(4^{\circ} \mathrm{C}, 15,000 \times \mathrm{g}\right)$ 하여, 상등액을 96-well plate로 옮기고 reaction buffer를 첨 가하여 $37^{\circ} \mathrm{C}$ 에서 30 분간 반응시켜 caspase- 3 substrate를 첨 가하고 1 시간 동안 $37^{\circ} \mathrm{C}$ 에서 반응시킨 후 $405 \mathrm{~nm}$ 에서 흡광 도를 측정하였다.

\section{통계처리}

모든 결과는 평균표표준편차로 나타내었으며, 통계적 유 의성 검증은 statistical analysis system(SAS, 9.3, SAS Institute Inc., Cary, NC, USA) 프로그램을 이용하여 one way ANOVA법으로 분산분석을 실시하고, Duncan의 다중 범위검정법(Duncan's multiple range test)으로 조사 항목들 간의 유의성을 $5 \%$ 수준에서 검증하였다.

\section{결과 및 고찰}

\section{항산화 효과}

본 실험에서는 오디 당침출액(MSE)을 40 일간 저장하면 서 10 일 간격으로 항산화 효과 측정을 측정하여 적정 저장 기간을 선정하여 세포 실험에 사용하고자 하였고, 측정 방 법으로는 DPPH radical scavenging을 이용하였다. DPPH radical 소거능은 식물 추출물 및 식품의 항산화 효과 측정을 위한 대표적인 방법으로, MSE의 측정 결과는 Fig. 1 과 같다. MSE 최종농도 $100 \mu \mathrm{g} / \mathrm{mL}$ 에 대하여 저장 기간 동안 DPPH radical 소거능은 증가하여, 저장 30 일과 40 일에는 각각 $65 \%$ 및 $66 \%$ 로 다른 저장 기간과 비교하여 유의적으로 높았으 나, 저장 30 일과 40 일간의 유의적 차이는 없었다. $\mathrm{Kim}$ 등 (22)은 오디 에탄올 추출물들 $(400 \mu \mathrm{g} / \mathrm{mL})$ 에서 $59 \sim 67 \%$ 에 $\mathrm{DPPH}$ radical 소거능을 나타냈다고 보고한 바 있다. 이상의 결과를 통해 이후 진행되는 세포 실험에는 40 일간 저장시 킨 오디 당침출액만을 사용하여 측정하고자 하였다.

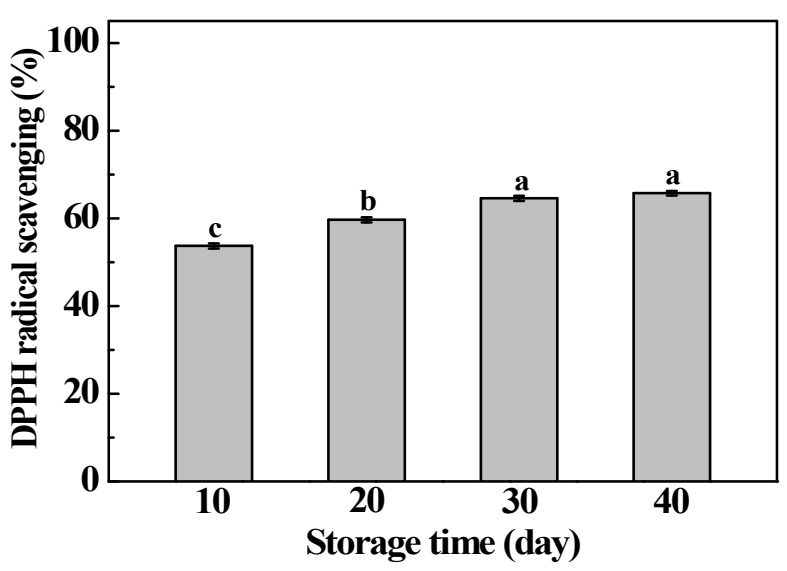

Fig. 1. Antioxidant effect of mulberry sugar extracts (MSE) during storage time.

The amount DPPH radical was determined spectrophotometrically at $517 \mathrm{~nm}$ following incubation with $100 \mu \mathrm{g} / \mathrm{mL}$ MSE for 40 days. The present data were expressed mean \pm SD. Means with different letters are significantly different by Duncan's multiple range test $(\mathrm{p}<0.05)$.

\section{세포 보호 효과 측정}

본 실험에서는 오디 당침출액을 통한 세포 보호 효과를 확인하고자 MTT assay 방법을 이용하여 세포 생존율을 확인하였다. 먼저, $\mathrm{HepG} 2$ 세포에 대한 $\mathrm{MSE}$ 의 세포독성을 확인하고자, MSE를 농도별 $(0.1,0.25,0.5 \%)$ 로 24시간 동안 처리 후 결과를 확인하였고, MSE 처리로 인한 세포독성은 나타나지 않았다(Fig. 2). 앞선 결과를 기초로, HepG2 세포 에 $\mathrm{H}_{2} \mathrm{O}_{2}$ 로 산화적 스트레스를 유발시켜 $\mathrm{MSE}$ 의 세포 생존 율을 확인하였고, 결과는 Fig. 3 과 같다. 세포 생존율 확인을 위해 시료를 24 시간 동안 $0.1,0.25,0.5 \%$ 농도로 전처리 후, $500 \mu \mathrm{M}$ 의 $\mathrm{H}_{2} \mathrm{O}_{2}$ 를 처리하여 확인하였다. $500 \mu \mathrm{M}$ 의 $\mathrm{H}_{2} \mathrm{O}_{2}$ 를 단독 처리한 세포의 경우, 세포 생존율이 $49 \pm 5.3 \%$ 로

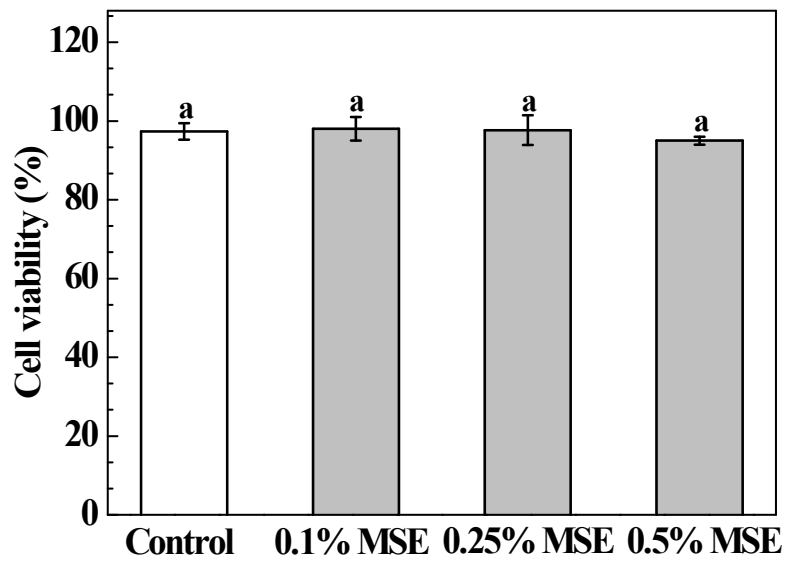

Fig. 2. Cytotoxic effects of mulberry sugar extracts (MSE) in HepG2 cells.

HepG2 cells were treated with MSE $(0,0.1,0.25$, and $0.5 \%)$ for $24 \mathrm{~h}$, and the cell viability was determined by MTT assay. The present data were expressed mean \pm SD. Means with different letters are significantly different by Duncan's multiple range test $(\mathrm{p}<0.05)$. 
감소한 반면, MSE를 농도별로 $(0.1,0.25,0.5 \%)$ 전처리 한 세포들의 경우, $69 \%, 61 \%$, 및 $64 \%$ 로, 세포 생존율이 $60 \%$ 이상으로 증가하여, $\mathrm{H}_{2} \mathrm{O}_{2}$ 로 인한 산화적 스트레스에 대해 $\mathrm{MSE}$ 의 세포 보호 효과를 확인하였다. 이와 관련하여, Park 등(7)은 오디 추출물 자체 독성에 대해 $2.5 \mathrm{mg} / \mathrm{mL}$ 이하의 농도로 오디추출물을 HepG2 세포에 처리할 경우 세포독성 없이 세포 생존율이 높았다고 보고한 바 있으며, Kim 등(22) 은 MIN6N $\beta$-cell에서 $\mathrm{H}_{2} \mathrm{O}_{2}$ 로 야기된 산화적 스트레스에 대해 오디 에탄올 추출물들 $(100 \mu \mathrm{g} / \mathrm{mL})$ 이 $62 ~ 73 \%$ 의 세포 생존율을 나타내었다고 보고한 바 있다.

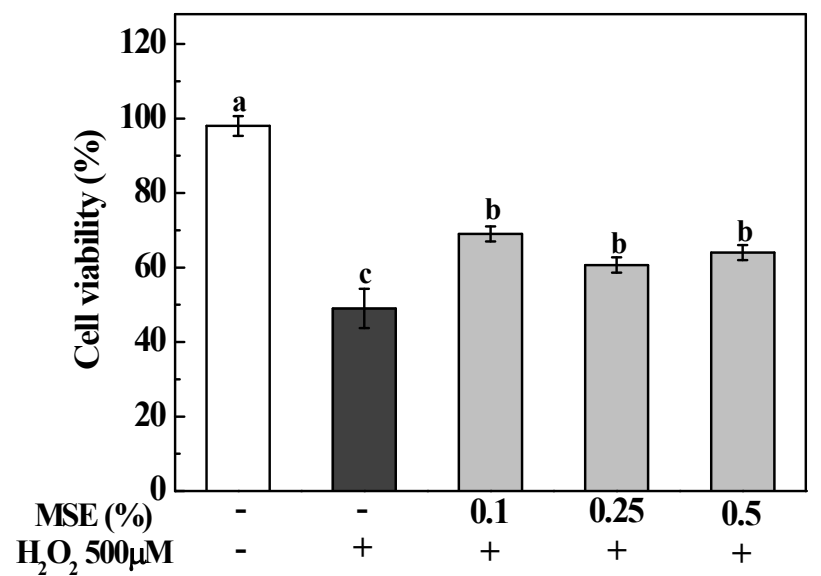

Fig. 3. Cytotoxic effects of mulberry sugar extracts (MSE) against $\mathrm{H}_{2} \mathrm{O}_{2}$-induced oxidative stress in $\mathrm{HepG} 2$ cells.

HepG2 cells were treated with vehicle or MSE $(0,0.1,0.25$, and $0.5 \%)$ in the presence of $500 \mu \mathrm{M} \mathrm{H} \mathrm{O}_{2}$ for $24 \mathrm{~h}$. The cell viability was determined by MTT assay. The present data were expressed mean \pm SD. Means with different letters are significantly different by Duncan's multiple range test $(\mathrm{p}<0.05)$.

\section{세포 내 지질과산화물(MDA) 생성 억제 효과}

지질과산화는 조직내 ROS 발생으로 인한 인지질 막 내 불포화지방산의 수소를 탈취함으로써 지질과산화(lipid peroxidation)의 연쇄반응이 진행되고, 최종 부산물로 malondialdehyde(MDA)등의 aldehyde를 생성하게 된다. 이 러한 부산물들은 세포나 조직막을 손상, 체액의 손실 및 단백질 변화등을 유발시켜 암, 동맥경화, 고혈압 등의 질병 을 유발하는 원인으로 작용한다(23). 이에, 본 실험에서는 산화적 스트레스로 인한 세포 손상의 증거로 지질과산화 생성물인 $\mathrm{MDA}$ 를 간접 측정하여 지질과산화물에 대한 $\mathrm{MSE}$ 의 억제 효과를 확인하고자 하였다(Fig. 4). HepG2 세 포에 아무것도 처리하지 않은 세포의 $\mathrm{MDA}$ 농도를 기준으 로, $500 \mu \mathrm{M}$ 의 $\mathrm{H}_{2} \mathrm{O}_{2}$ 를 단독 처리한 세포에서는 $\mathrm{MDA}$ 농도가 약 2.0배 증가한 반면, 세포에 MSE를 처리한 경우는 1.6배 증가하여, $\mathrm{H}_{2} \mathrm{O}_{2}$ 단독 처리군과 비교하여 약 0.4 배 감소한 것을 알 수 있었다. 이상의 결과를 통해, $\mathrm{MSE}$ 가 $\mathrm{H}_{2} \mathrm{O}_{2}$ 로 야기된 산화적 스트레스로 인한 세포 내 손상으로 증가된 지질과산화물(MDA)를 유의적으로 감소시켜 간세포 손상 을 억제시킴을 확인하였다. 오디에는 cyanidin-3-glucose , cyanidin-3-rutinoside 같은 anthocyanin, resveratrol 및 polyphenol 등이 다량 함유되어 있어 항산화 활성이 높은 것으로 알려져 있어(24,25), 산화적 스트레스와 관련된 만 성질환의 예방에도 도움이 될 것으로 생각된다.

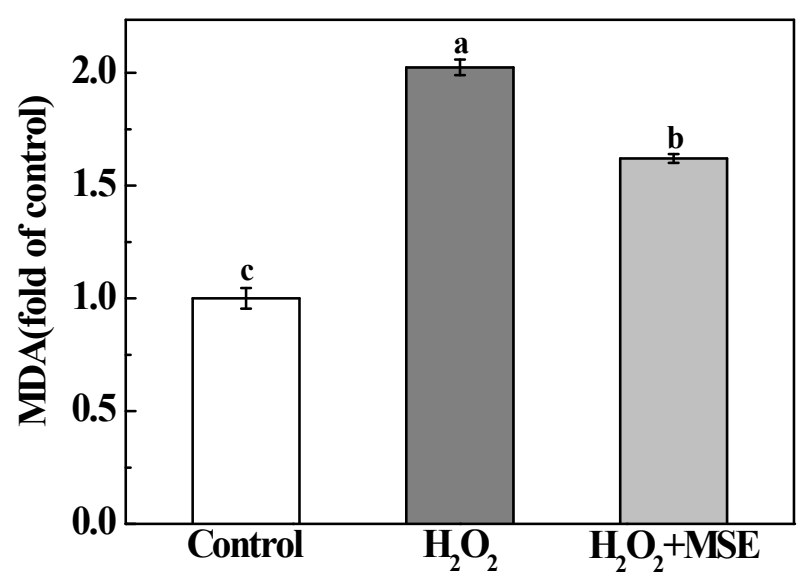

Fig. 4. Effects of mulberry sugar extracts (MSE) against $\mathrm{H}_{2} \mathrm{O}_{2}$-induced lipid peroxidation in $\mathrm{HepG} 2$ cells.

HepG2 cells were treated with vehicle or MSE $(0.5 \%)$ in the presence of $500 \mu \mathrm{M}$ $\mathrm{H}_{2} \mathrm{O}_{2}$ for $12 \mathrm{~h}$. The present data were expressed mean $\pm \mathrm{SD}$. Means with different letters are significantly different by Duncan's multiple range test $(\mathrm{p}<0.05)$.

\section{항산화 효소 활성 측정}

항산화 효소인 $\mathrm{SOD}$ 는 산화적 스트레스에 의해 세포 내 과잉 생성되는 $\mathrm{O} 2$-를 $\mathrm{H}_{2} \mathrm{O}_{2}$ 와 산소로 변화시키고, $\mathrm{CAT}$ 는 $\mathrm{H}_{2} \mathrm{O}_{2}$ 를 산소와 물로 변환시키는 역할을 통해 세포 내 radical을 소거함으로 인해 산화적 스트레스를 보호하는 것 으로 알려져 있다(26). 본 실험에서는 $\mathrm{H}_{2} \mathrm{O}_{2}$ 로 야기된 산화 적 스트레스로 증가된 radical의 억제시키는 체내 방어기전 인 항산화 효소들의 활성 측정을 통해 MES의 산화적 스트 레스에 대한 보호 효과를 확인하고자 하였다(Fig. 5,6). $\mathrm{HepG} 2$ 세포에 $\mathrm{H}_{2} \mathrm{O}_{2}$ 로 처리하여 12 시간 동안 $\mathrm{SOD}$ 활성을 측정한 결과, 시간 의존적으로 활성이 감소하여 측정 12 시 간에 SOD 활성이 $41 \%$ 로 감소한 반면, MSE를 처리한 세포 의 경우, 측정 12 시간에 $54 \%$ 로 $\mathrm{H}_{2} \mathrm{O}_{2}$ 만을 단독 처리한 세포 와 비교하여 SOD 활성이 $10 \%$ 이상 유의적으로 증가하였다 (Fig. 5). 또한, $\mathrm{CAT}$ 활성에서도 $\mathrm{H}_{2} \mathrm{O}_{2}$ 만을 단독 처리한 세포 에서는 시간 의존적으로 감소하여 측정 12 시간에 $46 \%$ 를 나타낸 반면, MSE를 처리한 세포에서는 $53 \%$ 를 나타내어 $\mathrm{H}_{2} \mathrm{O}_{2}$ 처리군에 비해 $\mathrm{CAT}$ 활성을 유의적으로 증가시킴을 확인하였다(Fig. 6). 이상의 결과는, $\mathrm{HepG} 2$ 세포에서 $\mathrm{H}_{2} \mathrm{O}_{2}$ 를 처리로 인하여 떨어진 항산화 효소들의 활성을 MSE가 증가시킴으로 인해 산화적 스트레스로 유발된 세포 내 손상 이 감소된 것으로생각된다.

\section{Apoptosis 억제 효과}

$\mathrm{H}_{2} \mathrm{O}_{2}$ 는 세포에서 많이 발견되는 활성산소종으로, 세포 


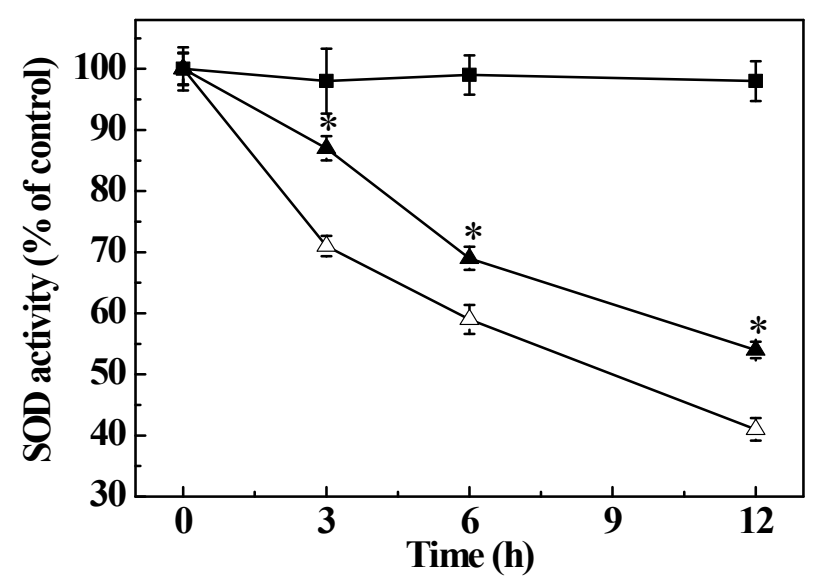

Fig. 5. Effects of mulberry sugar extracts (MSE) on antioxidant enzyme activity in $\mathrm{H}_{2} \mathrm{O}_{2}$ treated $\mathrm{HepG} 2$ cells.

$\mathrm{HepG} 2$ cells were treated with vehicle or MSE $(0.5 \%)$ in the presence of $500 \mu \mathrm{M}$ $\mathrm{H}_{2} \mathrm{O}_{2}$ for $12 \mathrm{~h}$. The present data were expressed mean $\pm \mathrm{SD}$. Means with different letters are significantly different by Duncan's multiple range test $(\mathrm{p}<0.05)$. $\mathbf{\square}$, control; $\triangle$, $500 \mu \mathrm{M} \mathrm{H}_{2} \mathrm{O}_{2} ; \boldsymbol{\Delta}, 500 \mu \mathrm{M} \mathrm{H}_{2} \mathrm{O}_{2}+0.5 \%$ MSE. SOD, superoxide dismutase.

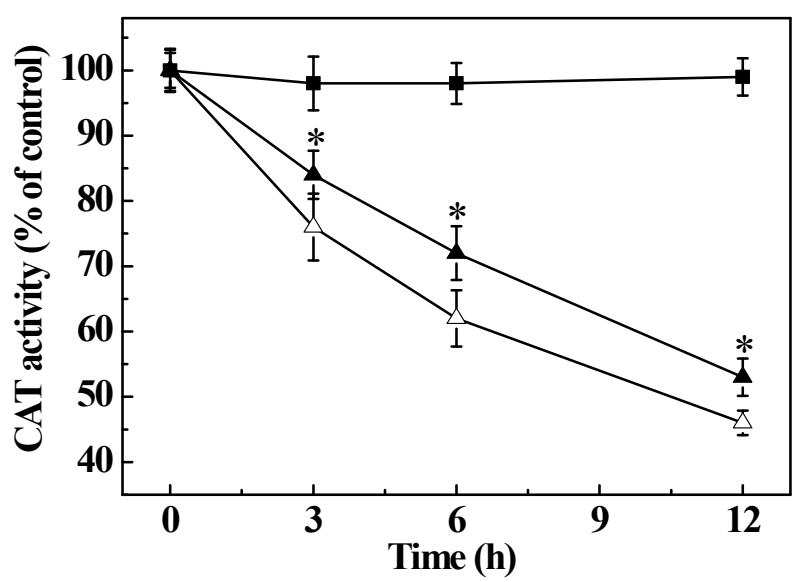

Fig. 6. Effects of mulberry sugar extracts (MSE) on antioxidant enzyme activity in $\mathrm{H}_{2} \mathrm{O}_{2}$ treated $\mathrm{HepG} 2$ cells.

HepG2 cells were treated with vehicle or MSE $(0.5 \%)$ in the presence of $500 \mu \mathrm{M}$ $\mathrm{H}_{2} \mathrm{O}_{2}$ for $12 \mathrm{~h}$. The present data were expressed mean $\pm \mathrm{SD}$. Means with different letters are significantly different by Duncan's multiple range test $(\mathrm{p}<0.05)$. $\mathbf{\square}$, control; $\triangle$, $500 \mu \mathrm{M} \mathrm{H}_{2} \mathrm{O}_{2}, \boldsymbol{\Delta}, 500 \mu \mathrm{M} \mathrm{H}_{2} \mathrm{O}_{2}+0.5 \%$ MSE. CAT, antioxidant enzyme activity of catalase.
막 통과가 용이하여 외부자극에 빠르게 반응하여 산화적 스트레스를 증가시킴에 따라 미토콘드리아 막전위를 감소 시켜 미토콘드리아 내부의 cytochrome c 방출을 촉진시켜 caspase-9과 caspase-3의 활성화를 통해 apoptosis를 유발시 키는 것으로 알려져 있다(27). 본 실험에서는 $\mathrm{H}_{2} \mathrm{O}_{2}$ 로 야기 된 산화적 스트레스로부터 유도되는 $\mathrm{HepG} 2$ 세포의 apoptosis의 형태학적 특징을 확인하기 위하여 Hoechst 33342 를 사용하여 핵을 염색하고 형광현미경으로 관찰하 였다(Fig. 7). 정상세포의 핵은 타원형의 온전한 형태를 나 타내었으나, $\mathrm{H}_{2} \mathrm{O}_{2}$ 를 처리한 세포의 핵은 condensation과 fragmentation으로 인한 apoptosis body가 핵 주변에 나타나 는 전형적인 apoptosis 특징을 나타내었다. 반면에, $0.5 \%$ 농 도의 MSE를 처리한 세포의 핵은 정상세포와 유사하게 타 원형의 온전한 핵 형태를 나타내어, $\mathrm{H}_{2} \mathrm{O}_{2}$ 로 야기된 산화적 손상에 대해 MSE가 세포를 보호하고 있음을 확인하였다. 이에 본 실험에서는 MSE의 apoptosis 보호 효과가 caspase-3

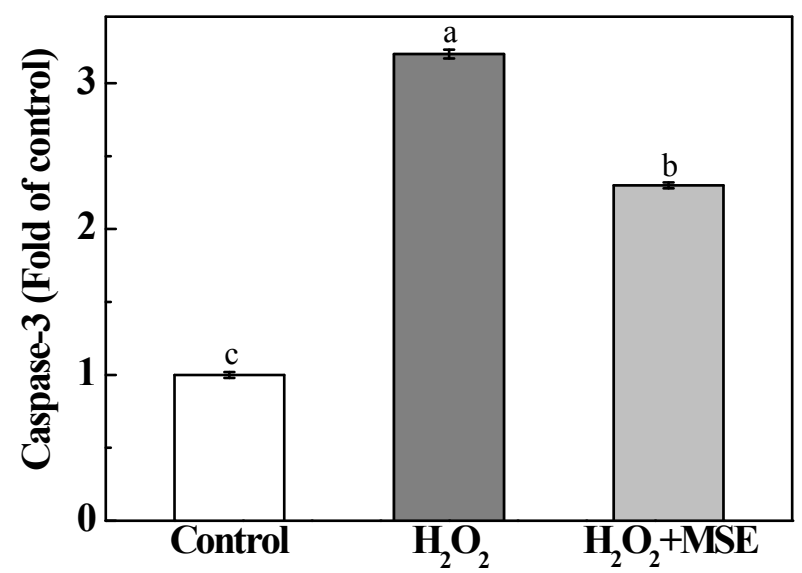

Fig. 8. Protective effect of mulberry sugar extracts (MSE) against $\mathrm{H}_{2} \mathrm{O}_{2}$-induced apoptosis in $\mathrm{HepG} 2$ cells.

The cells were treated with MSE and then stimulated with $500 \mu \mathrm{M} \mathrm{H} \mathrm{H}_{2} \mathrm{O}_{2}$ for $12 \mathrm{~h}$ The caspase- 3 activity was measured by the colorimetric assay. The present data were expressed mean \pm SD. Means with different letters are significantly different by Duncan's multiple range test $(\mathrm{p}<0.05)$.
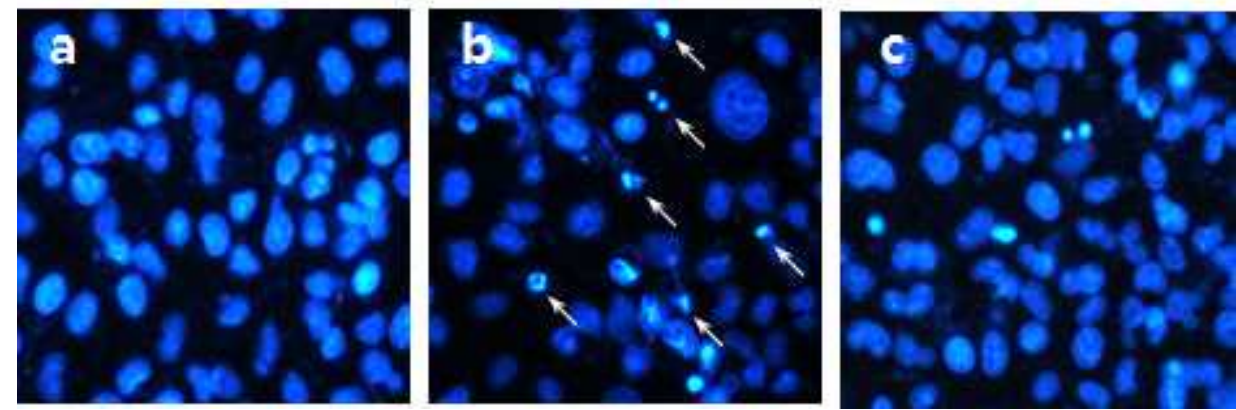

Fig. 7. Protective effect of mulberry sugar extracts (MSE) against $\mathrm{H}_{2} \mathrm{O}_{2}$-induced apoptosis in $\mathrm{HepG} 2$ cells.

The cells were treated with MSE and then stimulated with $500 \mu \mathrm{M} \mathrm{H} \mathrm{H}_{2}$ for $12 \mathrm{~h}$. Fixed cells were stained with Hoechst 33342 and examined by fluorescence microscope (Magnification $\times 400$, a: control, b: $500 \mu \mathrm{M} \mathrm{H} \mathrm{O}_{2}$, c: $500 \mu \mathrm{M} \mathrm{H} \mathrm{H}_{2} \mathrm{O}_{2}+0.5 \%$ MSE). 
와 관련이 있는지 확인하고자 caspase- 3 의 활성을 확인하였 다(Fig. 8). $\mathrm{HepG} 2$ 세포에 $\mathrm{H}_{2} \mathrm{O}_{2}$ 를 처리한 경우, caspase-3 활성이 control과 비교하여 3.2배 정도 증가한 반면, $\mathrm{MSE}$ 를 처리한 세포의 경우 2.3 배로 감소하였다. 이는, MSE가 $\mathrm{H}_{2} \mathrm{O}_{2}$ 로 야기된 apoptosis 과정에서 caspase- 3 의 활성 억제를 통한 간세포 내 산화적 손상을 감소시켜 세포를 보호한다는 것을 의미한다.

\section{요 약}

오디 당침출액(MSE)의 산화적 스트레스 개선 효과를 확인하기 위하여 $\mathrm{HepG} 2$ 세포에 $\mathrm{H}_{2} \mathrm{O}_{2}$ 로 산화적 스트레스를 유도시킨 다음, MSE의 보호효과를 확인하였다. MSE를 40 일간 저장하여 DPPH radical scavensing을 통해 DPPH radical 소거능이 유의적으로 좋았던 저장 40 일용 $\mathrm{MSE}$ 를 선택하여 세포 실험에 적용하였다. $\mathrm{HepG} 2$ 세포에 $500 \mu \mathrm{M}$ $\mathrm{H}_{2} \mathrm{O}_{2}$ 를 처리하여 산화적 스트레스를 유발시키고, MSE를 처리하여 세포 생존율을 확인한 결과, MSE 처리로 인한 세포 생존율이 유의적으로 증가하였고, ROS 생성과 과산 화물에 대한 지표로 측정된 MDA 농도도 MSE 처리로 인해 효과적으로 억제되었다. 또한, $\mathrm{H}_{2} \mathrm{O}_{2}$ 처리로 감소된 $\mathrm{SOD}$ 및 CAT 활성이 MSE 처리로 인해 유의적으로 높아졌으며, $\mathrm{H}_{2} \mathrm{O}_{2}$ 를 처리로 인한 세포핵의 apoptosis body가 MSE 처리 로 인해 감소함을 확인하였으며, 이는 caspase-3 활성 MSE 가 억제시킴으로 인해 세포를 보호하고 있음을 확인하였 다. 이상의 결과로부터 오디 당침출액은 산화적 스트레스 로부터 야기되는 세포독성과 apoptosis로부터 세포 보호 효과를 확인함에 따라 향후 노화와 관련된 다양한 연구 소재의 기초 자료 및 질병 예방 소재로의 가능성을 확인하 였다.

\section{감사의 글}

이 논문은 농촌진흥청 어젠다사업(과제번호 : PJ010005)의 지원에 의해 이루어진 것이며, 연구비 지원에 감사드립니다.

\section{References}

1. Jeong IY, Lee JS, Oh H, Jung UH, Park HR, Jo SK (2003) Inhibitory effects of hot-water extracts of Paeonia japonica on oxidative stress and identification of its active components. J Korean Soc Food Sci Nutr, 32, 739-744

2. Seo JE, Hwang ES, Kim GH (2011) Antioxidative and differentiation effects of Artemisia capillaris T. extract on hydrogen peroxide-oxidative damage of MC3T3-E1 osteoblast cells. J Korean Soc Food Sci Nutr, 40, 1532-1536

3. SEO JE, Kim GH (2012) Antioxidant activity and differentiation effect of Taraxacum mongolicum extracts against hydrogen peroxide-induced oxidative damage of MC3T3-E1 osteoblast cells. Korean J Food Cookery Sci, 28, 311-318

4. Kim YS, Jeong DY, Shin DH (2008) Optimum fermentation conditions and fermentation characteristics of Mulberry (Morus alba) wine. Korean J Food Sci Technol, 40, 63-69

5. Park SW, Chung IS, Ko GC (1997) Quantitative analysis of anthocyanins among mulberry cultivars and their pharmacological screening. J Korean Soc Food Sci Nutr, 38, 722-724

6. Jung GT, Ju IO, Choi DG (2005) Quality characteristics and manufacture of mulberry wine. Korean J Food Preserv, 12, 90-94

7. Park YS, Kang SS, Choi HJ, Yang SJ, Shon HH, Seo HH, Jeong JM (2014) Effect of mulberry (Morus alba L.) extract on blood flow improvement. J Korean Soc Food Sci Nutr, 43, 498-506

8. Du Q, Zheng J, Xu Y (2008) Composition of anthocyanins in mulberry and their antioxidant activity. J Food Composition Analysis, 21, 390-395

9. Shin SK, Kim HJ, Kim MR (2014) Effects of mulberry concentrate on lipid oxidation of Yackwa during its storage. Korean J Food Preserve, 21, 483-490

10. Kim SY, Park KJ, Lee WC (1998) Anti inflammatory and antioxidative effects of Morus spp. fruit extract. Korean J Seri Sc, 38, 100-107

11. Kim HB, Kim SY, Ryu KS, Lee WC, Moon JY (2001) Effect of methanol extract from mulberry fruit on the lipid metabolism and liver function in cholesterol-induced hyperlipidemia rats. Korean J Seri Sci, 43, 104-108

12. Kang CS, Ma SJ, Cho WD, Kim JM (2003) Stability of anthocyanin pigment extracted from mulberry fruit. J Korean Soc Food Sci Nutr, 32, 960-964

13. Kim AJ, Yuh CS, Bang IS, Park HY, Lee GS (2007) An investigation the preparation and physicochemical properties of oddi jelly using mulberry fruit power. Korean J Food Nutr, 20, 27-33

14. Park SY, Joo NM (2011) Processing optimization and antioxidant activity of chocolate added with mulberry. Korean J Food Sci Technol, 43, 303-314

15. Yoo SS, Jeong HC (2012) Quality characteristics of 
pound cake with added mulberry fruit power. J East Asian Soc Dietary Life, 22, 239-245

16. Shin SK, Kim HJ, Kim MR (2014) Quality characteristics of yackwa added with mulberry concentrate. J East Asian Soc Dietary Life, 24, 136-142

17. Hong JH, An SH, Park GS, Choi SW, Rhee SJ (2003) Quality characteristics of mulberry fruit Selgidduk added with citric acid. Korean J Soc Food Cookery Sci, 19, 777-782

18. Kim CR, yim SB, Kim HD, Oh HL, Jeon HL, Kim NY, Hong YP, Lee JH, Kim MR (2010) Change in the quality characteristics of salad dressing prepared with mulberry, Schidandra chinesis and yam juice during storage. Korean J Food Preserv, 17, 563-570

19. Jung GT, Ju IO, Choi DG (2005) Quality characteristics and manufacture of mulberry wine. Korean $\mathrm{J}$ Food Preserv, 12, 90-94

20. Kim KI, Kim ML (2013) Characteristics of wine fermented from mulberry juice. Korean J Culinary Res, $19,40-51$

21. Fraga CG, Leibovitz BE, Tappel AL (1998) Lipid peroxidation measured as thiobarbituric acid-reactive substance in tissue slices: characterization and comparison with homogenates and microsome. Free Radic Biol Med,
4, 155-161

22. Kim YR, Lee JS, Lee KR, Kim YE, Baek NI, Hong EK (2014) Effects of mulberry ethanol extracts on hydrogen peroxide-induced oxidative stress in pancreatic $\beta$-cells. Int J Mol Med, 33, 128-134

23. Hong CO, Hong ST, Koo YC, Yang SY, Lee JY, Lee YH, Ha YM, Lee KW (2011) Protective effect of Plantago asiatica L. extract against ferric nitrilotriacetate(Fe-NTA) induced renal oxidative stress in wistar rats. J Fd Hyg Safety, 26, 107-113

24. Park SW, Jung YS, Ko KC (1997) Quantitative analysis of anthocyanins among mulberry cultivars and their phamacological screening. Hortic Environ Biotechnol, 38, 722-724

25. Kim HB, Kim JB, Kim SL (2005) Varietal analysis and quantification of resveratrol in mulberry fruits. Korean J Seric Sci, 47, 51-55

26. Bobek P (1999) Dietary tomato and grape pomace in rat: effect on lipid in serum and liver, and on antioxidant status. Br J Biomed Sci, 56, 109-113

27. Kim HJ, Lee JM, Moon SH, Park HR (2010) Protective effect of Prunella spica extracts against $\mathrm{H}_{2} \mathrm{O}_{2}$-induced cytotoxicity in PC12 cells. J Life Sci, 20, 1121-1126 